\title{
4
}

\section{Casting her vote: Women's political participation in Solomon Islands}

\author{
Pauline Soaki \\ University of Melbourne
}

Women's political participation is recognised as a major factor in attaining gender equality in developing nations. In one of the reports on the Millennium Development Goals it is stated that 'Development policies and actions that fail to take gender inequality into account and fail to address disparities between males and females will have limited effectiveness and serious cost implications' (Birdsall, Ibrahim and Rao 2004: iv). In Solomon Islands, female participation in democratic processes has only recently been seriously considered and the impetus has come mainly from external agencies such as United Nations Development Fund for Women (UNIFEM, now UN Women). International agencies have emphasised participation in government and encouraged women to stand for election. In 2008, the Solomon Islands Government Caucus received a submission from women's groups to introduce reserved seats for women led by the committee for Women In Shared Decision-Making (WISDM). To date nothing has eventuated.

In this chapter, I draw on research with women voters and women who have been candidates in national elections to explore some of the reasons why it is so difficult for women to be elected. I look at some of 
the ways that women conceptualise voting. Recent scholarly works and reports on women's political participation have mostly concentrated on encouraging women to contest seats in parliament or assemblies, and much less attention has been paid to women's involvement as voters. The studies by Ronald Inglehart and Pippa Norris and other foreign observers (Inglehart and Norris 2000, 2003; Inglehart, Norris and Welzel 2002) on voting behaviour and voters' turnout included women's political participation; and the analyses by Jon Fraenkel (2006) and Jeffrey Steeves (2011) on political behaviour highlight the gaps in research on female voters. Terence Wood's (2012b) study of Solomon Islands elections and his article on the impediments to women's electoral success (2014) stand as the only in-depth examinations of women's political participation in Solomon Islands.

Solomon Islands is an ethnically diverse country, with an estimated population of 515,870 people (National Statistics Office 2009: 22; UNDP 2002) of which 80 per cent live in rural areas, in village settings with subsistence economies (UNDP 2002). The country gained its independence in 1978, inheriting the Westminster political system and institutions from its former coloniser, Britain. Although an independent state, Solomon Islands has retained much of its colonial and missionary heritage, adopting and reaffirming their conservative and patriarchal ideologies. The British administration was exclusively male and established the model of employment in the public service as predominantly masculine. In its encouragement of cash cropping and plantation work, it stressed that such employment was exclusively male (McDougall 2003). While the situation has altered since independence, the view that women should 'stay in the village' and be wives and mothers remains strong. Missionaries stressed the domestic role of Christian mothers, teaching skills in housekeeping, sewing and cooking. In many respects, these colonial attitudes reinforced the male dominance that characterised precolonial society. Today women are citizens in a postcolonial state, but very few consider standing for election and, when they do, they gain little support from women voters.

Solomon Islands has nine provinces, which are politically divided into 50 constituencies, and total 164 political wards (Cox and Morrison 2004). The National Parliament has 50 seats for the Members of Parliament (MPs). The government in office governing with ministerial portfolios form the Cabinet, and MPs without portfolios make up the Caucus. The Honiara City Council has 12 Wards, and the Mayor heads 
the council. In the provinces, the provincial ward members form the Provincial Government with the Premier as the head. In the 35 years of independence, Solomon Islands has had only one woman occupy a seat in the National Parliament for two terms, from 1989 to 2001 (Commonwealth Secretariat 2010; Dinnen and Firth 2008; Fraenkel 2006; Huffer 2006). In the provincial assemblies, women have fared better-an indication of changes in the perception of women's capacity for political leadership. In 2009, only six women were elected to Provincial Assemblies. For the Western Provincial election, with 26 wards in the province, of the eight women who contested, the only (and first) woman to win a provincial seat was from Ward 14, Kusaghe of North New Georgia. In the following election, Ward 10 Irinqila elected a woman candidate, making her the second woman to win a seat. The first woman unfortunately lost her seat in 2011. Hilda Kari became the first and, until 2012, the only female member of the National Parliament when she successfully contested the 1989 by-election for the North East Guadalcanal seat after it was vacated by Waita Ben Tabusasi (q.v.) when he became Speaker. She was re-elected as member for East Central Guadalcanal in 1994 and 1997. Vika Lusibaea was the second woman to enter the National Parliament through a byelection in 2012, after her husband vacated the North Malaita seat. In the most recent elections in 2014, 49 men and only one woman, Freda Soria Comua, were elected to parliament. The 2014 election results suggest that contesting elections will continue to be very difficult for women.

With growing awareness of gender equality, and support by the Pacific bodies and Pacific states, 26 women together with 427 men contested the 2006 national elections for the 50 seats in parliament. Not one of the women was successful, and neither were 377 of the men aspiring to hold a seat in the eighth parliament. In 2010, a record number of 508 individuals stood for election, surpassing the 453 in 2006. The overwhelming majority were men as the number of women contesting fell from 26 in 2006 to 22 . No women candidates were elected to the 2010 parliament (RNZ Pacific 2010; Steeves 1996; McMurray 2012; Wood 2012b). Thus, viewed from an historical perspective, it would seem that women's parliamentary political participation has declined.

There are significant challenges to women's autonomous voting decisions in Solomon Islands that also affect the chances of female candidates. Women are not voting for women, and we need to examine factors that determine the decisions made by women who vote in national and provincial elections. Women in political office or leadership positions can influence other women 
through their investment in policy and programs for women's issues. They can also change conditions in politics through more conscious, concerted, direct attention to women's concerns. A single woman with a strong party affiliation or high position in political office could contribute to reshaping politics, and lobbying for pushing the agenda for modernisation processes that improve the lives of people. According to John Wells Kingdon and James A. Thurber (1984), these individuals are called policy entrepreneurs. Although there are debates surrounding the feminisation of the position (for example, women in leadership are often put in roles that are more focused on social development or in health and education), it is clear that when placed in particular ministries, women can have an influence (for example, Dame Carol Kidu in Papua New Guinea's parliament). However, it is overly optimistic to expect that pro-women policies are inevitable. Kidu's successor, Delilah Gore, has repudiated proposals for affirmative action and undone some of the excellent reforms Dame Carol introduced. Few Solomon Islands women have been given the opportunity to become policy entrepreneurs, although in recent years the concerted actions of women's organisations, especially during peace negotiations, have shown that when they combine forces, they can achieve goals that benefit all.

Women's organisations are generally regarded as core initiative takers in issues concerning gender and women's development. Globally, the UN and bilateral donor partners have effectively championed the implementation of policies for women's strategic needs and empowerment. In Solomon Islands, women's organisations have been a force for change that has grown tremendously since the crisis experience in 1998-2003. They have increasingly occupied public space, and so created some confidence in women's ability to participate in the public sphere. These actors take on effective leadership initiatives in both the formal and informal sectors while making progress within the broader community (Pollard 2003). According to Francis Fukuyama (2001), such organisations draw and rely on their social capital, the networks essential for efficient knowledge sharing and action through empowerment within formal institutions of the rule of law and rationality. Social capital, he maintains, is less easily created or shaped by policy interventions but can be cultivated by policy entrepreneurs. However, these organisations entail a built-in complexity where it is not clear who is behind a decision and how much of a role conformity plays in its function within the governing state. In most cases, these actors can only 
act within the political parameters permitted by the state. In the Solomons, while there are indications that women have the capacity to act in the public domain in their own interest, social constraints remain.

Two main structural factors influence the ways that people generally, and women themselves, conceptualise the roles and capacities of women in society. The first is the historical conservatism of a patriarchal structure that endorses kastom and traditional norms; and the second is the longterm effect of imperial colonial ideologies that imposed new religious norms and beliefs. The latter reinforced the long tradition of women having lower status in public life. In Solomon Islands, where government has a fairly remote relationship to everyday life, the effect of both these structural forces has been to legitimate surveillance over women's lives while enforcing conformity to both the traditional values and the introduced Christian religiosity. At the same time, women are excluded from public decision-making, defined as 'men's business'.

There is a considerable literature on gender roles and the position of women in Melanesian societies. Bronwen Douglas (2003) characterises the dichotomy between the 'traditional' and 'modern' woman in Solomon Islands and the contrasting approaches to discerning the reality of the women's everyday life. On one side is the romanticisation of the rural setting - of living in a thatched house, cooking on the open fire, eating food gathered or grown, drinking from the stream, bathing in the rivers, and dancing at night-as enticing and utopic. However, on the other side, Douglas (2003) highlights the concerns of John Connell (1984) about women's oppression: subjugated by the patriarchal traditions and cultural norms, victims of physical violence from male relatives, overworked and burdened by domestic chores, and living in almost total submission to their men.

Alice Aruhe'eta Pollard (2000b) and Douglas (2003) maintain that the hegemonic feminist 'ideology of female subordination to men' exaggerates their oppression. ${ }^{1}$ Pollard writes:

1 For instance, Roger M. Keesing (1985) explains how Kwaio men considered menstruating women polluting, so women would be sent away to live in seclusion. However, these women saw it as voluntary and used this isolation as rest from hard domestic chores and an occasion to socialise with other women. 
women do not actually see their role in society as degrading ... Solomon Islands woman is proud of herself and her supportive role; she knows that the success of husbands - as of men in general-is simply a reflection of the success of their wives, and of women in general (2000b: 4).

Ratna Kapur (2002) criticises Western emphasis on female subordination, maintaining that such representations of women as victims effectively diminishes their gender status and their capacities to act in their own interests.

However, a further examination of those who present a more positive view of 'traditional' female roles does little to dispel the idea that they are subordinate to men. Pollard (2000a, 2000b) maintains that, traditionally, women were brought up to respect their elders, to be nurturant in their social roles, to be good daughters, good wives, and daughters-in-law and mothers. Douglas (2003) and Christine Dureau (1993) argue that Melanesian women generally are socialised from infancy to be domestic, respectful, and passive. Bruce M. Knauft (1997) and Hilary Charlesworth (2008), with others, acknowledge that Melanesian women are considered the backbone of domestic life but all concede that their contribution to non-domestic decisions is limited or even non-existent. Kenneth Brown and Jennifer Corrin Care (1998) explain that women's status lies in the gendered roles they occupy as child bearers and in domestic labour-roles that do not prepare them for political participation in the public sphere.

The condition and status of women today varies from place to place and reflects their adaptation to the existing socioeconomic structures and the political institutions that define them, with a distinct dichotomy between 'traditional' and 'modern' women. My research revealed some clear distinctions between women in town and those in rural areas. ${ }^{2}$ Rural communities have continued to maintain strong attachments to kastom and traditional control over women, but the situation is more complicated in urban areas. People from different regions live side by side, and the network of kin relationships is fragmented. But only a small percentage of women, notably those who have benefited from higher education and are familiar with more cosmopolitan ways of life, question their social position and resist the surveillance of their lives in terms of religion and kastom. In discussions with women, many indicated that higher education

2 Research was conducted with women in White River, Honiara, and women in Kusaghe and Irigilla, Western Province, in June and July 2014. 
and experience of travel overseas were desirable qualities in a political candidate; however, they expected such women to conform to behaviours and attitudes that were more parochial and limited.

Brown and Care (1998) maintain that regulation of the customary regime not only maintains male power and control, but the structures and institutions of customary society are dominated by males to the point where women in effect are subtly prohibited from ever having authority over men. Women who were candidates in elections tended to agree with this view. This has implications in employment as well as in political contests. For example, Asenati Liki (2010) insisted that the right to equal opportunity in the work place endorses the right of suitably qualified women to occupy senior positions on the basis of merit; but in practice the assumption of a senior or managerial position by a Solomon Islands woman would be viewed as an inappropriate intrusion into 'big man' public space and status.

It is difficult to escape the view that women should not intrude into the male domain. Marion Ward (1995) reinforces the gendered position with specific advice to the Women's Development Division to investigate income-generating projects, credit schemes and so on, for women engage in-as gender-specific activities. These proposed schemes are quite different from those usually proposed for men and emphasise domestic activities such as sewing clothes and selling cooked food. Unwittingly perhaps, Ruth Liloqula and Alice Aruhe'eta Pollard validate the impression of a subordinate gendered position by attesting to the 'core value of motherliness' (2000: 9) ascribed to Melanesian women, with natural attributes of 'God-given qualities such as love, care, peace' (ibid.). She legitimises women's gendered position through their various contributions and responsibilities in the areas of production, reproduction, family welfare, community work and conflict resolutions, and nation building (Charlesworth 2008; Douglas 2003; Dureau 1993). Writers stress women's agency and capabilities in meeting the basic and practical needs of families, especially in communities. However, Pollard (2003) also highlighted women's unprecedented organised public interventions to help resolve conflict during the ethnic and political crisis afflicting Solomon Islands from 1999-2001. Similarly, many have attested to the value of women's gendered cultural identity and their acceptance of Christian duty as peacemakers (Charlesworth 2008; Pollard 2003; Scheyvens 2003; Webber and Johnson, 2008). Nevertheless, the roles specified reinforce the distinction between the gendered spheres of position and responsibilities, with women consistently represented as 'maternal' and having qualities that are inherently 
different from those of men. In the Solomons, men view these as precisely the qualities that justify women's exclusion from the political sphere. In short, women can have influence publicly, but this is only valued when it involves actions and attitudes that are consistent with cultural stereotypes of women as gentle, motherly and ameliorative.

\section{Women as voters}

A total of 40 women voters were interviewed, 20 from urban communities in Honiara and 20 from the rural community of Irinqila, all of whom had voted in elections at the provincial and national levels. While voting is not compulsory, almost all regarded voting as a moral duty. This view is interesting, mainly because they did not connect this obligation to citizenship - indeed, many did not recognise the word and the others held very limited ideas about what citizenship entailed, confining their answer to notions of obedience to the law. However, when asked to specify how they knew about impending elections, the answers were more revealing. A woman in Gizo replied:

You know when it's near elections when you get invited to go and eat in some supporter's house or when there is a donation to the local church or school by some intending candidate.

Someone you've never known to have an interest in you suddenly becomes generous and kind to you, offering financial assistance (translated from Solomon Islands Pidjin, Irinqila participant, Gizo, July 2014).

At White River, in urban Honiara, just over a third of the women mentioned that candidates or their supporters came to their houses and gave them money, telling them who to vote for and how to vote. None had received anything since the election. While in most countries this would be considered bribery, in the Solomons gifts of money and other items to individuals and to communities are so common as to be considered a standard method of campaigning.

The obligation to vote was seen mainly as a Christian duty, often one carried out at the behest of husbands. Very few women had an understanding of the duties or obligations of parliamentarians, of the policies of particular parties, or the names of parliamentarians other than their own elected members at provincial and national level. Ten per cent of the rural women did not recognise the term Member of Parliament, responding to the question only 
when it was explained as 'big man' (MP) and 'small member' (Provincial Member). Seventy per cent of the urban women knew the names for the Members of Parliament representing their constituency as well as the MP for their places of origin, and because they read newspapers, all could name the Prime Minister and Governor General. Generally, rural women did not know the name of the Governor General or the Prime Minister-only 40 per cent named the Prime Minister and 15 per cent the Governor General. Many did not know how the Prime Minister was elected, or even that he was a Member of Parliament himself. In short, few women had a full understanding of their country's system of government. In spite of this they vote in elections; indeed, voter turnout is usually quite high.

All the women who participated in the study were registered voters and had voted in elections, some on more than two occasions. Their participation is driven by their own motivations but within boundaries of socially determined obligations, defining who they are as persons rather than as citizens. That is, they think of voting as a way of furthering private interests, rather than having a say in the broader, national interest. In some respects, we could say that their reasons are not political at all and have little to do with an embrace of their rights.

They all described their motivations as the moral duty of a good person, often linking the imperatives to Christianity, rather than seeing them in terms of citizenship. Conversations with the women in Ward 14 Kusaghe, a stronghold of the Christian Fellowship Church (CFC), indicated that all the women who were of eligible age voted according to the decree of their religious leader who guides and mandates decisions over politics, economic matters, resource distribution and labour allocation. None of the women could define citizenship and all perceived voting as an activity that was considered virtuous within a Christian framework rather than a secular duty. They perceive their vote as being for their community.

When its election time, my husband tells me who to vote for, because it's announced at the church gathering, the name of the candidate we must vote for (translated from Solomon Islands Pidjin, Kusaghe participant, 40 years, July 2014).

Many of the women in the research claimed to have some interest in political issues, with 20 per cent of the women in White River and 50 per cent of respondents in Irinqila affirming their concern that politicians had good policies. However, when asked to elaborate they spoke exclusively of the benefits that they hope will flow to their 
community from the MP or Ward Member. These are conceptualised as personal favours by the elected member rather than duties inherent to the office, as highlighted by John Cox (2009). This is evident from the White River women's responses where 60 per cent said that the member played a 'welfare role', by which they meant assistance in the form of cash handouts. Rural women shared similar views, although the percentage differs. In this context, 33 per cent of women described their MP as having a 'welfare role', namely providing cash to individuals who requested assistance for school fees, funeral and medical costs. Alongside this, 42 per cent of the women stressed the 'development provider' role, by which they meant tangible benefits in the form of a community rest-house, solar panel for lighting, and a school outboard motor.

The subjects of women's rights, democracy and modern ideologies that favour women's political autonomy and independence-ideas that challenge ideologies of kastom and the church-held little interest for the women. These were described as foreign concepts, opposed to kastom and to the teachings of the church, and women either expressed their reservations about them or were unaware of the terms. According to a woman in Gizo:

Women who came to talk to us about these women rights, we know them to be separated from their husband, and that is not what we want, we don't want to talk about women's right and have our husband leave us.

No, I hear some women talking about it but I don't know what it means, but when the older women talk about women's rights, they say that in our kastom, it's unacceptable.

These concepts belong to Honiara; they don't come down to the province and raise awareness of what national government say [about] gender equality and women's rights. The policies and implementation plans of the government are hardly made known to women at provincial and village level (translated from Solomon Islands Pidjin, President Provincial Council of Women, Gizo, July 2014).

Many hold fast to ideas that exclude women from engaging with modernity: to the belief that it is a waste of time and money to educate girls; the view that girls are indispensable in the village because they are more hardworking than boys; the fear that girls may 'play around' and become pregnant or marry outside their communities (with a consequent loss of control over marriage exchanges and bride price payments); or are concerned that girls will enter the Westernised urban world and adopt unacceptable attitudes 
and behaviours (Billy 2002; Connell 1984). The modernists, who are mainly educated, urban women, stress the emancipating power of human rights discourses in the form of opportunities and equality to participate and occupy public space, and freedom to manoeuvre around restrictive kastom boundaries. These sorts of attitudes adversely affected Afu Billy's political career, when she stood for election, with opponents describing her as a 'wayward' daughter, a 'black sheep', and one who was not only educated but was absent from church, and engaged in a questionable marital relationship, and who rarely goes to the villages (Billy 2002).

In interviews, women voters claimed that they applied the same moral judgements to male candidates, emphasising that they valued someone who was a 'good person'-meaning morally upright, a regular churchgoer, lawabiding and kind. When asked if a man who beat his wife was 'good', the majority ( 60 per cent) said that this would depend upon his reasons for doing so. They believed that a husband had the right to discipline his wife using violence if she had been immoral or in some way been a 'bad wife'. These attitudes draw on customary ideas about male privilege and authority within the family - ideas that underpin more general views about the 'naturalness' of male dominance over women. For example, a study in Solomon Islands on family violence revealed that of the 64 per cent of women aged between 15 and 49 who experienced intimate partner violence, 70 per cent of these women accept and justify their partner's action as his cultural duty to discipline a disobedient wife (World Vision 2009). Given that violence against women is viewed internationally as a major problem in Melanesia, this response reveals that female candidates who campaign against domestic violence as a women's issue might not necessarily gain female support. In fact, many comments about women candidates suggest that they are often subjected to much harsher judgements about their morality and behaviour than their male counterparts (see also Wood 2014: 1).

Women interviewed were unconcerned about the political performance of representatives based on policy development and successful implementation of national strategies. This is mainly because they have no idea about the government's plans and policies. These are available but not easily accessible to the majority of women, many of whom are illiterate or too inhibited to raise questions about such matters, or too burdened with domestic responsibilities to seek out this information. 
Although women in the study indicated a willingness to vote for a woman, women who had stood for election believed that there were strong social reasons why women did not do so. In particular, they explained this as resistance to the idea of a woman gaining wealth or power over others:

Some women are jealous when they see a female candidate contest for election, and this might be because they have past encounters that turned bad, or they think that if that woman wins, she might become wealthy and own things. But such thinking is not levelled at the male candidates (previous female candidate, Central Honiara, June 2014).

Jealousy is big in our society; women are not working together because they are also competing for positions of employment, in small business activities, and owning materialistic wealth. They don't want to see another woman have easy access to these things (previous female candidate, North New Georgia, July 2014).

If a woman in Vella wants to contest, no one is going to vote for her because of jealousy; we don't want one of our women to have a higher, prestigious position over us. It would be impossible for the men to accept or vote for a woman in Vella in elections (translated from Solomon Islands Pidjin, participant, Irinqila, July 2014).

Women are jealous of each other when it comes to supporting someone who might accumulate wealth and power, especially a woman who is known to have unstable marital relationship, or be promiscuous or even have a thriving business (translated from Solomon Islands Pidjin, participant, White River, August 2014).

If the reluctance of women to vote for female candidates because of jealousy is one factor, there are other structural factors that limit their chances of success. Solomon Islands elections use the plurality formula, also known as first-past-the-post (FPTP), for its simplicity. To be elected, a candidate simply needs to have more votes than any opponents. However, even simplicity does not prevent political consequences, which from the outset disadvantages female candidates competing on a 'tilted playing field'. First, they are already hampered by existing social norms and values; and second, the winning candidate does not always get even half of the majority votes — and often gets less. As Terence Wood explains:

[The] majority of candidates who have stood in Solomon Islands elections since 1980 have won low vote shares, winning less than 10 per cent of the votes cast in their electorates. However, low vote shares are even more pronounced for women candidates (2014a: 2). 
Jon Fraenkel's book, The Manipulation of Custom: From Uprising to Intervention in the Solomon Islands (2004) and Steeves' article, "Unbounded politics" and the democratic model in Solomon Islands: The 2010 national elections' (2011) offer confronting analyses of Solomon Islands politics. Both authors (and others) share the view that Solomon Islands Members of Parliament since independence were political 'big men' who were recognised primarily for their traditional status and their popularity often derived from their roles in the independence movement (Fraenkel 2004; Fraenkel and Grofman 2005; Steeves 2011; Wood 2012a). Reflecting on the successful careers of men such as Solomon Mamaloni, Sir Peter Kenilorea, Sir Baddley Devesi and Paul Tovua, who were regarded as the fathers of independence, Fraenkel and Bernard Grofman (2005) suggested the recognition of their names has carried weight in the minds of voters. Jack Corbett and Terence Wood (2013) attributed the election of Makira MP David Sitai, whose father had been a leader before independence, and also of North New Georgia MP Dudley Job Tausinga, as an indication of loyal base voters in their constituencies.

However, name alone does not necessarily impress voters, as female candidates who contested the 2006 elections found. Those with recognisable names because of their family connections, or prominence in the feminist movement, in community development initiatives, the church, or those who had prestigious careers-such as Sarah Dyer, Dr Alice Pollard and Afu Billy-were unable to secure seats in parliament, even though they campaigned strongly, promising to bring constituents' concerns and needs to the floor of parliament (Billy 2002; RNZ Pacific 2010; Steeves 2011).

Several scholars have suggested that changes in recent elections reflect patterns of patronage having greater salience in voters' choices than other factors. This patron/client system can be attributed to the establishment of the Rural Constituency Development Fund (RCDF) in 1992, which provided funds directly to the MPs for assistance to their local constituents (Randell 1999). In 1994, the total of the fund was $\$ 6$ million, allocating $\$ 200,000$ for each constituency (Randell 1999: 36). Wood (2012a), Fraenkel (2004), Cox (2009) and Steeves (2011) all commented on the fact that new election candidates, mostly men, have deployed gifts and money handouts to the point where political clientelism has emerged as a major factor in successful election. The Commonwealth Secretariat (2010) highlighted this trend whereby voters see the candidates' capacity to provide them with gifts and money prior to an election as more important 
than their qualifications or ability to engage in national policy formation. Steeves (2011) attributed some results directly to candidates' largesse in the 2010 elections. These scholars conclude that with the political climate becoming more community-development focused, the surprising shift was the fact that a number of political veterans who were contesting for their second or more terms were rejected by their constituents (Fraenkel and Grofman 2005; Steeves 1996). Wood's analysis of the 2014 elections indicates that this pattern of patronage and bribery persists. My own study confirmed the role of payments and gifts, both to individuals and communities, as the major factors that influenced people's judgements about what constituted a good candidate. The provision of services by government is extremely poor and people have low expectations of the state as a provider of health, education, transport and communication infrastructure and services. Often the elected representative's gift of a boat or roofing iron for a communal facility is perceived as 'government' support for a particular community and this suffices as a reason for electoral support.

The disappointing election results in 2006 and 2010 for Solomon Islands' women candidates provided the impetus for the Ministry of Women, Youth, Children and Family Affairs, together with international bodies, to push to make provisions to enable women to have equal opportunity in political participation. Solomon Islands ratified the Convention on the Elimination of All Forms of Discrimination against Women (CEDAW) in 2002, but the government has been slow to develop and implement action plans as directed by provisions made in the convention (Solomon Star 2010; Solomon Islands Government 2014). Article 4 of CEDAW specifically provides for the adoption of 'temporary special measures aimed at accelerating the de facto equality between men and women'. Elise Huffer (2006) and Abby McLeod (2007) interpret the provision as aimed at encouraging countries to adopt affirmative action to redress the imbalance in men's and women's positions in society, including increasing political representation.

Various reports have observed that even with regional commitments and gender policy reforms, with funding for gender awareness projects (Eminent Persons' Group 2004; Huffer 2006; McLeod 2007; Norris 1968) and an emphasis upon training for women candidates, little has changed. Pacific nations continue to have the lowest level of women in parliament in the world (Corbett 2013; Eminent Persons' Group 2004; Huffer 2006; McLeod 2007; Norris 1968) with women only representing 
4.1 per cent of parliamentarians in the Pacific, well below the world average of 16 per cent (Fraenkel 2006; Huffer 2006). Statistics from international organisations show that Solomon Islands currently has one female MP, Papua New Guinea has three and Vanuatu has zero. Fraenkel (2006) warns that gender inequality in Pacific parliaments is often not simply a reflection of women's performance in education or their position in the top echelons of the civil service, since they have been advancing strongly in these areas over recent decades, but rather is specific to elected assemblies, which remain largely male-controlled.

Solutions to the problems of female representation and developing policies that respond to the problems and disadvantages that ordinary women face are likely to take some time. It is clear from my study that there is an urgent need for civic education that could raise awareness about the system of government and the responsibilities of parliamentarians. This might contribute to a more critical attitude towards the forms of corruption that prevail and in turn enable female candidates to gain more support. The obstacles that currently impede women's political participation as voters and candidates are a complex mix of conservative attitudes to women's roles, economic disadvantage, low educational attainment and a moral double standard that advantages men. There are social changes required on many fronts to alter the situation for Solomon Islands women and to ensure that they are able to cast their votes independently.

\section{References}

Billy, Afu. 2002. 'Fighting for a fair deal in national politics'. Development Bulletin 5: 58-61.

Birdsall, Nancy, Amina J. Ibrahim, Gupta Geeta Rao. 2004. 'Task Force 3 Interim Report on Gender Equality', 1 February 2004. New York: Millennium Project. Online: www.unmillenniumproject.org/ documents/tf3genderinterim.pdf (accessed 4 July 2016).

Brown, Kenneth and Jennifer Corrin Care. 1998. 'Conflict in Melanesia: Customary law and the rights of women'. Commonwealth Law Bulletin 24(3-4): 1334-355. doi.org/10.1080/03050718.1998.9986517.

Charlesworth, Hilary. 2008. 'Are women peaceful? Reflections on the role of women in peace-building'. Feminist Legal Studies 16(3): 347-61. doi.org/10.1007/s10691-008-9101-6. 
Commonwealth Secretariat. 2010. 'Solomon Islands National Parliamentary Elections 2010'. In Report of the Commonwealth Observer Group. London: Commonwealth Secretariat.

Connell, John. 1984. 'Status or subjugation? Women, migration and development in the South Pacific'. In Women in Migration. Special Issue: International Migration Review 18(4) (Winter): 964-83. doi. org/10.2307/2546068.

Convention on the Elimination of All Forms of Discrimination against Women (CEDAW). 1979. UN Women. Online: www.un.org/ womenwatch/daw/cedaw/text/econvention.htm (accessed 11 December 2014).

Corbett, Jack. 2013. "'A calling from God": Politicians and religiosity in the Pacific Islands'. Global Change, Peace and Security 25(3): 283-97. doi.org/10.1080/14781158.2013.810616.

Corbett, Jack and Terence Wood. 2013. 'Profiling politicians in Solomon Islands: Professionalisation of a political elite?' Australian Journal of Political Science 48(3): 320-34. doi.org/10.1080/10361146.2013. 821100 .

Cox, John. 2009. 'Active citizenship or passive clientelism? Accountability and development in Solomon Islands'. Development in Practice 19(8): 964-80. doi.org/10.1080/09614520903220784.

Cox, John and Joanne Morrison. 2004. 'Solomon Islands Provincial Governance information paper'. Provincial Government. Canberra: Australian Agency for International Aid.

Dinnen, Sinclair and Stewart Firth. 2008. Politics and State Building in Solomon Islands. Canberra: ANU E Press. Online: press.anu.edu. au/publications/politics-and-state-building-solomon-islands (accessed 22 August 2016).

Douglas, Bronwen. 2003. 'Christianity, tradition, and everyday modernity: Towards an anatomy of women's groupings in Melanesia'. Oceania 74(1-2): 6-23. doi.org/10.1002/j.1834-4461.2003.tb02833.x.

Dureau, Christine. 1993. 'Nobody asked the mother: Women and maternity on Simbo, Western Solomon Islands'. Oceania 64(1): 18-35. doi.org/10.1002/j.1834-4461.1993.tb02445.x. 
Eminent Persons' Group. 2004. 'Review of the Pacific Islands Forum'. April. Online: www.iri.edu.ar/publicaciones_iri/anuario/CD\%20 Anuario\%202005/Asia/47-pacific\%20island\%20forum-eminent $\% 20$ persons\%20report\%2004.pdf (accessed 23 August 2016).

Fraenkel, Jon. 2006. 'The impact of electoral systems on women's representation in Pacific parliaments'. Report 2. A Report Conducted for the Pacific Islands Forum Secretariat by the Pacific Institute of Advanced Studies in Development \& Governance (PIAS-DG). Online: iknowpolitics.org/sites/default/files/report_120and202_-_the_impact_ of_electoral_systems_57_-_106.pdf (accessed 23 August 2016).

\section{- 2004 . The Manipulation of Custom: From Uprising to Intervention in} the Solomon Islands. Wellington: Victoria University Press.

Fraenkel, Jon and Bernard Grofman. 2005. 'Introduction - Political culture, representation and electoral systems in the Pacific Islands'. Commonwealth \& Comparative Politics 43(3): 261-75. doi. org/10.1080/14662040500304783.

Fukuyama, Francis. 2001. 'Social capital, civil society and development'. Third World Quarterly 22(1): 7-20. doi.org/10.1080/713701144.

Huffer, Elise. 2006. 'Desk review of the factors which enable and constrain the advancement of women's political representation in Forum Island countries'. Report. Pacific Islands Forum Secretariat (PIFS). Online: www.forumsec.org/resources/uploads/attachments/ documents/report_1_-_a_desk_review_of_the_factors_18_-_56. pdf (accessed 23 August 2016).

Inglehart, Ronald and Pippa Norris. 2003. Rising Tide: Gender Equality and Cultural Change around the World. Cambridge: Cambridge University Press. doi.org/10.1017/CBO9780511550362.

—_. 2000. 'The developmental theory of the gender gap: Women's and men's voting behavior in global perspective'. International Political Science Review 21(4): 441-63. doi.org/10.1177/0192512100214007.

Inglehart, Ronald, Pippa Norris and Christian Welzel. 2002. 'Gender equality and democracy'. Comparative Sociology 1(3-4): 321-45. doi. org/10.1163/156913302100418628. 
Kapur, Ratna. 2002. 'The tragedy of victimization rhetoric: Resurrecting the "native" subject in international/post-colonial feminist legal politics'. The Harvard Human Rights Journal 15: 1-37.

Keesing, Roger M. 1985. 'Kwaio women speak: The micropolitics of autobiography in a Solomon Island society'. American Anthropologist 87(1): 27-39. doi.org/10.1525/aa.1985.87.1.02a00040.

Kingdon, John Wells and James A. Thurber. 1984. Agendas, Alternatives, and Public Policies, vol. 45. Boston: Little, Brown.

Knauft, Bruce M. 1997. 'Gender identity, political economy and modernity in Melanesia and Amazonia'. Journal of the Royal Anthropological Institute 3(2): 233-59. doi.org/10.2307/3035018.

Liki, Asenati. 2010. 'Women leaders in Solomon Islands Public Service: A personal and scholarly reflection'. State, Society and Governance in Melanesia, discussion paper 2010/1. Canberra: The Australian National University.

Liloqula, Ruth and Alice Aruhe'eta Pollard. 2000. 'Understanding conflict in Solomon Islands: A practical means to peacemaking'. State, Society and Governance in Melanesia, discussion paper 00/7. Canberra: The Australian National University.

McDougall, Debra. 2003. 'Fellowship and citizenship as models of national community: United Church Women's Fellowship in Ranongga, Solomon Islands'. Oceania 74(1-2): 61-80. doi. org/10.1002/j.1834-4461.2003.tb02836.x.

McLeod, Abby. 2007. 'Literature review of leadership models in the Pacific'. State, Society and Governance in Melanesia, research paper. Canberra: The Australian National University.

McMurray, Christine. 2012. 'National elections and women candidates in Solomon Islands: Results from the People's Survey'. In Centre for Democratic Institutions Policy Papers on Political Governance, CDI PPS 2012/1, pp. 1-17. Canberra: The Australian National University.

National Statistic Office. (2009). 'Basic tables and census description'. In Solomon Islands 2009 Population and Housing Census. Honiara, Solomon Islands: National Statistic Office, Ministry of Finance. 
Norris, Ada. 1968. 'Women's political participation in the South Pacific'. The Annals of the American Academy of Political and Social Science. 375(1): 96-101. doi.org/10.1177/000271626837500115.

Norris, Pippa and Ronald Inglehart. 2000. 'Cultural barriers to women's leadership: A worldwide comparison'. International Political Science Association World Congress IPSA 2000, pp. 1-30. Montreal: International Political Science Association.

Pollard, Alice Aruhe'eta. 2006. 'Painaha: Gender and leadership in 'are'are Society, the South Sea Evangelical Church and Parliamentary Leadership-Solomon Islands'. PhD thesis. Victoria University of Wellington.

Pollard, Alice A. 2003. 'Women's organizations, voluntarism, and selffinancing in Solomon Islands: A participant perspective'. Oceania 74(1-2): 44-60. doi.org/10.1002/j.1834-4461.2003.tb02835.x.

—_. 2000a. 'Resolving conflict in Solomon Islands: The women for peace approach'. Development Bulletin 53: 44-46.

—_. 2000b. Givers of Wisdom, Labourers without Gain: Essays on Women in the Solomon Islands, ed. Anthony R. Walker. Suva: Institute of Pacific Studies, the University of the South Pacific; Honiara: University of the South Pacific Centre.

Randell, Shirley. 1999. 'Towards quality governance in Solomon Islands'. Department of Provincial Government and Rural Development. Honiara: SRI Public Sector Reform Pty Ltd.

RNZ Pacific. 2010. 'Lack of money behind the failure of women in Solomon Islands election'. Radio New Zealand Pacific, 10 August. Online: www.radionz.co.nz/international/pacific-news/191929/ lack-of-money-behind-the-failure-of-women-in-solomons'-election (accessed 23 August 2016).

Scheyvens, Regina. 2003. 'Church women's groups and the empowerment of women in Solomon Islands'. Oceania 74(1-2): 24-43. doi. org/10.1002/j.1834-4461.2003.tb02834.x.

Solomon Islands Government. 2014. Solomon Islands CEDAW Combined Initial, Second and Third Periodic Report 2012 (W. Division, Trans.). Honiara: Ministry of Women, Youth, Children and Family Affairs. 
Solomon Star. 2010. 'Solomon Islands Government defies CEDAW agreements: Delma’. Solomon Star, 10 July.

Steeves, Jeffrey. 2011. "Unbounded politics" and the democratic model in Solomon Islands: The 2010 national elections'. Commonwealth \& Comparative Politics 49(3): 342-58. doi.org/10.1080/14662043.2 011.582733 .

—. 1996. 'Unbounded politics in the Solomon Islands: leadership and party alignments'. Pacific Studies 19(1): 115-38.

United Nations Development Programme (UNDP). 2002. Solomon Islands Human Development Report 2002: Building a Nation, vol. 1, edited by Mark Otter. St Lucia: University of Queensland.

Ward, Marion Wybourn. 1995. Pacific 2010: Women and Employment in Solomon Islands. Pacific Policy Papers 16. National Centre for Development Studies, Research School of Pacific and Asian Studies, Canberra: The Australian National University.

Webber, Katherine and Helen Johnson. 2008. 'Women, peace building and political inclusion: A case study from Solomon Islands'. Hecate 34(2): 83-99.

Wood, Terence. 2014. 'Why can't women win? Impediments to female electoral success in Solomon Islands'. Discussion paper, Centre for Democratic Institute, Canberra: The Australian National University.

- 2012a. 'Poor political governance in Solomon Islands - is culture the cause?' 21 August. DevPolicyBlog. Development Policy Centre. Online: devpolicy.org/poor-political-governance-in-solomon-islands-what-userational-choice-explanations20120821/ (accessed 23 August 2016).

- 2012b. 'Why voting in Solomons is unlikely to simply be driven by clan identity'. Waylaid Dialectic, 29 July. Online: waylaiddialectic. wordpress.com/2012/07/29/why-voting-in-solomons-is-unlikely-tosimply-be-driven-by-clan-identity/ (accessed 23 August 2016).

World Vision. 2009. Tackling Gender Based Violence in the Solomon Islands. Online: www.worldvision.com.au/global-issues/work-we-do/poverty/ tackling-gender-based-violence (accessed 23 August 2016). 
This text is taken from Transformations of Gender in Melanesia, edited by Martha Macintyre and Ceridwen Spark, published 2017 by ANU Press, The Australian National University, Canberra, Australia. 